\title{
PENGARUH JENIS PENGOLAHAN DAN LAMA PEMERAMAN TERHADAP KANDUNGAN FRAKSI SERAT PELEPAH KELAPA SAWIT
}

\section{The Effect of Types of Processing and Different of Curing Time on Fiber Fraction of Oil Palm Fronds}

\author{
Dewi Febrina*, Rizky Pratama, Rahmi Febriyanti
}

Faculty of Agriculture and Animal Sciences, State Islamic University of Sultan Syarif Kasim Riau Jln. H.R. Soebrantas Km 15.5, Pekanbaru, Riau 28293

*E-mail: hanna_suska@yahoo.com

Submitted : May 26, $2020 \quad$ Accepted : July 12, 2020

\begin{abstract}
ABSTRAK
Pemanfaatan pelepah kelapa sawit sebagai pakan terkendala karena tingginya kandungan lignin. Jenis pengolahan dan lama pemeraman yang berbeda diharapkan dapat menurunkan kandungan fraksi seratnya terutama kandungan lignin. Penelitian ini bertujuan untuk mengetahui kandungan fraksi serat pelepah kelapa sawit dengan jenis pengolahan dan lama pemeraman berbeda. Penelitian mengunakan Rancangan Acak Lengkap dengan pola faktorial dengan 2 faktor masing-masing dengan 3 ulangan sehingga terdapat 27 unit perlakuan. Faktor A adalah jenis pengolahan: A1 pengolahan secara kimia (penambahan urea 5\%); A2 pengolahan secara biologi (penambahan eksreta 10\%); A3 pengolahan secara kimia + biologi (penambahan $5 \%$ urea $+10 \%$ eksreta). Faktor B adalah lama pemeraman: B1 pemeraman 7 hari; B2 pemeraman 14 hari; B3 pemeraman 21 hari. Data dianalisis menggunakan analisis sidik ragam (Analysis of Variance/ANOVA) dan dilanjutkan dengan uji jarak berganda Duncan. Hasil penelitian menunjukkan jenis pengolahan, lama pemeraman dan interaksi antara jenis pengolahan dengan lama pemeraman menurunkan kandungan selulosa dan hemiselulosa dan lignin serta meningkatkan kandungan NDF dan ADF. Perlakun terbaik adalah kombinasi pengolahan secara kimia + biologi (penambahan urea 5\% dan eksreta 10\%) dengan lama pemeraman 21 hari karena menghasilkan kandungan ADL terendah yaitu 18,94\%.
\end{abstract}

Kata kunci : Eksreta, Fraksi serat, Pemeraman, Pelepah kelapa sawit, Urea.

\section{ABSTRACT}

The utilization of oil palm fronds as feed is constrained because of the high lignin content. Different types of processing and curing time are expected to reduce the fiber fraction content, especially lignin content. This study aims to determine the content of fiber fractions of oil palm fronds with different types of processing and ripening time. The study used a Complete Randomized Design with Factorial, 2 factors each with 3 replications so that there were 27 treatment units. Factor $A$ is the type of processing: A1. chemical processing (5\% urea addition); A2. biological processing (addition of $10 \%$ eksreta); A3.chemical + biological treatment (addition of 5\% urea $+10 \%$ eksreta). Factor B is the duration of curing: B1. 7 days; B2. 14 days; B3. 21 days. Data were analyzed using Analysis of Variance (ANOVA) and continued with Duncan Multiple Range Test. The results showed the type of processing, curing duration, and interaction between types of processing and curing time decreased cellulose and hemicellulose and lignin content and increased NDF and ADF content. The best treatment is chemical + biological treatment (addition of 5\% urea and $10 \%$ eksreta) with a ripening duration of 21 days because it produces the lowest ADL content of $18.94 \%$.

Keywords: Curing, Excreta, Fiber fraction, Oil palm fronds, Urea. 


\section{PENDAHULUAN}

Luas perkebunan kelapa sawit di Riau pada tahun 2017 mencapai 2.703.199 Ha, meningkat pada tahun 2018 menjadi 2.739.571 Ha (Dirjen Perkebunan, 2018). Pelepah kelapa sawit merupakan limbah lapangan dari perkebunan kelapa sawit. Peluang pemanfaatan pelepah kelapa sawit sebagai pakan sangat besar yaitu 1,64 ton/ha/tahun bahan kering (Diwyanto et al., 2003), tapi terkendala dengan tingginya kandungan lignin yaitu 30,18\% (Febrina, 2016).

Perlakuan secara kimia (penambahan urea), biologi (penambahan mikroorganisme) dan kombinasi kimia dan biologi dapat menurunkan kandungan lignin pelepah kelapa sawit. Febrina et al., (2020) melaporkan penambahan urea 5\% pada proses fermentasi pelepah kelapa sawit menghasilkan kandungan lignin $21,57 \%$ dan penambahan feses ayam $10 \%$ menghasilkan kandungan lignin terendah (19,94\%). Penambahan urea $4 \%$ pada amoniasi pelepah kelapa sawit menurunkan kandungan lignin (Imsya et al., 2007) dan meningkatkan kecernaan (Nurhaita et al., 2007). Penambahan $4 \%$ urea dan $15 \%$ feses ayam pada fermentasi pelepah kelapa sawit meningkatkan konsentrasi $\mathrm{N}_{-} \mathrm{NH}_{3}$ dan kecernaan bahan kering dan bahan organik (Imsya, 2007).

Lama pemeraman memberikan pengaruh terhadap kandungan fraksi serat. Hal ini berhubungan dengan fase pertumbuhan mikroba selama proses pemeraman Fermentasi pelepah kelapa sawit dengan kapang Phanerochaete chrysosporium selama 10 hari menurunkan kandungan NDF (Wardani, 2013; Febrina et al., 2015). Terjadi peningkatan kandungan selulosa dan penurunan hemiselulosa pelepah kelapa sawit yang difermentasi dengan Trichoderma sp seiring dengan meningkatnya lama pemeraman (Jaelani dkk., 2015). Penelitian ini bertujuan untuk mengetahui kandungan fraksi serat pelepah kelapa sawit dengan jenis pengolahan dan lama pemeraman berbeda

\section{MATERI DAN METODE}

\section{Materi}

Penelitian dilaksanakan di Laboratorium Nutrisi dan Teknologi Pakan Fakultas Pertanian dan Peternakan UIN SUSKA RIAU, analisis kandungan fraksi serat dilaksanakan di Laboratorium Analisis Hasil Pertanian Fakultas Pertanian UNRI. Penelitian menggunakan bahan yang terdiri dari pelepah kelapa sawit, urea, feses ayam dan aquadest. Alat yang digunakan adalah mesin pencacah, timbangan, plastik, selotip, sarung tangan, ember, serta peralatan untuk analisis fraksi serat.

\section{Metode}

Metode dilakukan dengan langkah mencacah pelepah kelapa sawit menggunakan mesin pencacah (leaf chopper), mengeringkan kemudian menimbang hasil cacahan; mengeringkan eksreta ayam secara manual dengan bantuan panas matahari kemudian menggiling dengan mesin grinder; mencampurkan bahan berdasarkan Febrina et al (2020) yaitu menambahkan urea 5\% dan eksreta $10 \%$ pada bak plastik sehingga semua bahan tercampur merata selanjutnya menambahkan aquadest sesuai kebutuhan; memadatkan untuk mengurangi udara dalam kantong selanjutnya plastik dilapisi sebanyak 3 lapis; proses pemeraman dilakukan sesuai dengan perlakuan yaitu pemeraman selama 7, 14 dan 21 hari, setelah pemeraman selesai membuka hasil fermentasi dan mengeringkan selanjutnya menggiling dan menganalisis kandungan fraksi serat.

Penelitian menggunakan Rancangan Acak Lengkap (RAL) pola faktorial $3 \times 3$ dengan 3 ulangan, dengan dua faktor penelitian yaitu faktor A (jenis pengolahan) dan faktor B (lama pengeraman).

$A_{1}$ : Pengolahan secara kimia (5\% urea)

$\mathrm{A}_{2}$ : Pengolahan secara biologi (10\% eksreta ayam broiler terdapat bakteri Lactobacilus achidopilus, Lactobacilus reutri, Leuconostoc mesenteroides dan Streptococus thermophiles menurut Sari, 2012)

$\mathrm{A}_{3}$ : Pengolahan secara kimia dan biologi (5\% urea $+10 \%$ eksreta)

$\mathrm{B}_{1} \quad$ : pemeraman 7 hari

$\mathrm{B}_{2}$ : pemeraman 14 hari

$\mathrm{B}_{3}$ : pemeraman 21 hari

Peubah yang diukur pada penelitian ini adalah kandungan NDF, ADF, Selulosa, hemiselulosa dan lignin. Semua data dianalisis dengan analisis sidik ragam (analysis of variance) dan perbedaan antar perlakuan diuji dengan uji jarak berganda Duncan (Duncan Multiple Range Test) (Steel dan Torrie, 1992).

\section{HASIL DAN PEMBAHASAN}

Hasil penelitian menunjukkan jenis pengolahan dan lama pemeraman mempengaruhi $(\mathrm{P} \leq 0,01)$ kandungan fraksi serat pelepah kelapa sawit. Terdapat interaksi $(\mathrm{P} \leq 0,01)$ antara jenis 
pengolahan dan lama pemeraman terhadap kandungan fraksi serat pelepah kelapa sawit, kecuali pada kandungan ADF (Tabel 1).

Jenis pengolahan yang berbeda secara nyata $(\mathrm{P} \leq 0,01)$ mempengaruhi kandungan fraksi serat pelepah kelapa sawit. Perlakuan secara kimia (penambahan urea) menyebabkan terhidrolisisnya urea menjadi ammonia sehingga pelepah kelapa sawit mengalami swealling yang merenggangkan ikatan lignoselulosa dan lignohemiselulosa akibatnya selulosa dan hemiselulosa terlepas dari lignin. Hidrolisis urea dapat merenggangkan ikatan lignin dan selulosa (Marjuki, 2012). Hal ini disajikan pada Tabel 1 perlakuan secara kimia (penambahan urea) menghasilkan kandungan selulosa, hemiselulosa dan lignin tertinggi dan sangat nyata $(\mathrm{P} \leq 0,01)$ berbeda dibandingkan perlakuan lainnya (perlakuan biologi dan biologi dan kimia).

Perlakuan secara biologi (penambahan eksreta) menghasilkan kandungan selulosa, hemiselulosa dan lignin lebih rendah dibandingkan perlakuan kimia (penambahan urea). Hal ini disebabkan karena eksreta mengandung N 2,94\% (Suharyadi, 2012) yang dapat berfungsi sebagai sumber protein bagi mikroba sehingga mikroba dapat memperbanyak diri dan menghasilkan enzim lebih banyak lagi, selain itu eksreta juga mengandung Bakteri Asam Laktat (Lactobacilus achidopilus, Lactobacilus reutri, Leuconostoc mesenteroides dan Streptococus thermophilus) (Sari, 2012) ; mengandung bakteri selulolitik $63 \times 10^{7} \mathrm{cfu} / \mathrm{g}$, dengan aktivitas selulase tertinggi $(0,906 \mathrm{U} / \mathrm{ml})$ pada suhu $37^{\circ} \mathrm{C}$, jam ke-14 dan $\mathrm{pH} 4,48$ (Febriyossa et al., 2013). Jannah et al. (2017) juga melaporkan pada isi sekum ayam kampung jumlah bakteri selulotik adalah 5,3 x $10^{5} \mathrm{cfu} / \mathrm{g}$, lebih tinggi dibandingkan dengan yang dilaporkan Spring (1997) pada sekum ayam broiler jumlah bakteri selulolitik berkisar $10^{3} \mathrm{cfu} / \mathrm{g}$. Hal inilah yang diduga mempercepat penguraian senyawa kompleks menjadi senyawa sederhana sehingga perlakuan secara biologis menghasilkan kandungan kandungan selulosa, hemiselulosa dan lignin yang lebih rendah.

Tabel 1. Kandungan Fraksi Serat Pelepah Kelapa Sawit dengan Jenis Pengolahan dan Lama Pemeraman Berbeda (Contents of Oil Palm Frond Midrib Fiber Fraction with Different Types of Processing and Curing Time)

\begin{tabular}{|c|c|c|c|c|c|}
\hline & $\begin{array}{l}\text { erlakuan } \\
\text { reatment }\end{array}$ & $\begin{array}{l}\text { B1(7 hari) } \\
\text { B1(7 days) }\end{array}$ & $\begin{array}{l}\text { B2 (14 hari) } \\
\text { B2 (14 days) }\end{array}$ & $\begin{array}{l}\text { B3 (21 hari) } \\
\text { B3 (21 days) }\end{array}$ & $\begin{array}{l}\text { Rata-rata } \\
\text { Average }\end{array}$ \\
\hline Kandungan & A1(kimia) & $57,32 \pm 0,14^{\mathrm{aA}}$ & $58,24 \pm 0,27^{\mathrm{bA}}$ & $59,00 \pm 0,22^{\mathrm{cA}}$ & $58,19^{\mathrm{a}}$ \\
\hline NDF & A2(biologi) & $57,59 \pm 0,08^{\mathrm{aAB}}$ & $58,29 \pm 0,03^{\mathrm{bA}}$ & $59,43 \pm 0,10^{\mathrm{cB}}$ & $58,44^{\mathrm{b}}$ \\
\hline$(N D F$ & A3(kimia+biologi) & $57,79 \pm 0,28^{\mathrm{aB}}$ & $58,50 \pm 0,09^{\mathrm{bA}}$ & $59,70 \pm 0,14^{\mathrm{cB}}$ & $58,66^{\mathrm{c}}$ \\
\hline Content) & Rata-rata & $57,57^{\mathrm{A}}$ & $58,34^{\mathrm{B}}$ & $59,38^{\mathrm{C}}$ & \\
\hline Kandungan & A1(kimia) & $44,58 \pm 0,10$ & $46,02 \pm 0,29$ & $47,69 \pm 0,25$ & $46,09^{\mathrm{a}}$ \\
\hline ADF & A2(biologi) & $44,79 \pm 0,24$ & $46,76 \pm 0,13$ & $48,85 \pm 0,29$ & $46,80^{\mathrm{a}}$ \\
\hline$(A D F$ & A3(kimia+biologi) & $45,19 \pm 0,34$ & $47,05 \pm 0,11$ & $49,19 \pm 0,55$ & $47,14^{\mathrm{b}}$ \\
\hline Content) & Rata-rata & $44,85^{\mathrm{A}}$ & $46,61^{\mathrm{B}}$ & $48,44^{\mathrm{C}}$ & \\
\hline Kandungan & A1(kimia) & $22,46 \pm 0,03^{\mathrm{cB}}$ & $22,03 \pm 0,04^{\mathrm{bC}}$ & $21,14 \pm 0,02^{\mathrm{aC}}$ & $21,88^{\mathrm{c}}$ \\
\hline Selulosa & A2(biologi) & $22,35 \pm 0,16^{\mathrm{cAB}}$ & $21,79 \pm 0,05^{\mathrm{bB}}$ & $20,89 \pm 0,05^{\mathrm{aB}}$ & $21,68^{b}$ \\
\hline (Selulose & A3(kimia+biologi) & $22,19 \pm 0,05^{\mathrm{cA}}$ & $21,53 \pm 0,13^{\mathrm{bA}}$ & $20,05 \pm 0,21^{\mathrm{aA}}$ & $21,26^{\mathrm{a}}$ \\
\hline Content) & Rata-rata & $22,33^{\mathrm{C}}$ & $21,78^{\mathrm{B}}$ & $20,69^{\mathrm{A}}$ & \\
\hline Kandungan & A1(kimia) & $12,73 \pm 0,16^{\mathrm{cA}}$ & $12,23 \pm 0,34^{\mathrm{bB}}$ & $11,31 \pm 0,19^{\mathrm{aC}}$ & $12,09^{\mathrm{c}}$ \\
\hline Hemiselulosa & A2(biologi) & $12,80 \pm 0,21^{\mathrm{cA}}$ & $11,53 \pm 0,11^{\mathrm{bA}}$ & $10,97 \pm 0,20^{\mathrm{aB}}$ & $11,77^{\mathrm{b}}$ \\
\hline (Hemiselulose & A3(kimia+biologi) & $12,60 \pm 0,49^{\mathrm{cA}}$ & $11,45 \pm 0,19^{\mathrm{bA}}$ & $10,51 \pm 0,53^{\mathrm{aA}}$ & $11,52^{\mathrm{a}}$ \\
\hline Content) & Rata-rata & $12,71^{\mathrm{C}}$ & $11,74^{\mathrm{B}}$ & $10,83^{\mathrm{A}}$ & \\
\hline Kandungan & A1(kimia) & $21,16 \pm 0,15^{\mathrm{cB}}$ & $20,29 \pm 0,04^{\mathrm{bA}}$ & $19,85 \pm 0,10^{\mathrm{aC}}$ & $20,43^{\mathrm{c}}$ \\
\hline Lignin & A2(biologi) & $20,88 \pm 0,16^{\mathrm{cB}}$ & $20,15 \pm 0,08^{\mathrm{bA}}$ & $19,50 \pm 0,19^{\mathrm{aB}}$ & $20,18^{\mathrm{b}}$ \\
\hline (Lignin & A3(kimia+biologi) & $20,48 \pm 0,15^{\mathrm{cA}}$ & $20,03 \pm 0,02^{\mathrm{bA}}$ & $18,94 \pm 0,26^{\mathrm{aA}}$ & $19,82^{\mathrm{a}}$ \\
\hline Content) & Rata-rata & $20,84^{\mathrm{C}}$ & $20,16^{\mathrm{B}}$ & $19,43^{\mathrm{A}}$ & \\
\hline
\end{tabular}

Keterangan: Superskrip huruf yang berbeda pada baris dan pada kolom yang sama menunjukkan pengaruh yang berbeda sangat nyata $(\mathrm{P} \leq 0,01)$ (Different letter superscripts in the same row and column showed a very significant different effect $(\mathrm{P} \leq 0,01))$.

Kombinasi pelakuan kimia dan biologi (penambahan $5 \%$ urea dan $10 \%$ eksreta) menghasilkan kandungan selulosa, hemiselulosa dan lignin terendah dan sangat nyata $(\mathrm{P} \leq 0,01)$ berbeda dengan perlakuan lainnya. Hal ini menunjukkan sinergi yang baik antara urea dan 
eksreta. Eksreta juga berfungsi sebagai sumber urease yang akan mempercepat penguraian urea menjadi ammonia yang akan mempercepat proses pemecahan lignoselulosa dan lignohemiselulosa sehingga selulosa dan hemiselulosa dapat dimanfaatkan sebagai sumber energi bagi mikroba.

Peningkatan lama pemeraman dari 7 hari menjadi 14 hari dan 21 hari sangat nyata $(P<0,01)$ meningkatkan kandungan NDF dan ADF, tapi menurunkan kandungan selulosa, hemiselulosa dan lignin pelepah kelapa sawit. Hal ini berhubungan dengan fase-fase pertumbuhan mikroorganisme yang terdiri atas 4 fase yaitu fase pertumbuhan awal (lag phase), fase eksponensial (log phase), fase istirahat (stationary phase) dan fase kematian (death phase).

Pada pemeraman 7 hari, diduga bakteri berada pada fase adaptasi (lag phase), artinya bakteri melakukan adaptasi terhadap lingkunganya termasuk nutrisi. Populasi bakteri belum bertambah dalam jumlah yang signifikan, tetapi bakteri sudah mulai melakukan aktivitasnya dengan mengeluarkan enzim tapi dalam jumlah yang sedikit. Pada kondisi ini diduga bakteri mengeluarkan selulase tapi dalam jumlah yang sedikit yang dapat memecah lignoselulosa dan lignohemiselulosa, terpecahnya lignoselulosa dan lignohemiselulosa menyebabkan selulosa dan hemiselulosa larut dan menjadi bentuk yang sederhana dan mudah dimanfaatkan oleh bakteri sebagai sumber energinya, akibatnya kandungan selulosa dan hemiselulosa menurun. Menurunnya kandungan selulosa dan hemiselulosa menyebabkan peningkatan kandungan NDF dan ADF.

Pada hari ke-14 bakteri berada pada fase $\log$, yaitu fase pertumbuhan cepat (eksponensial) dimana bakteri tumbuh dengan cepat dan jumlahnya juga bertambah dengan sangat cepat sehingga enzim yang dihasilkan juga lebih banyak. Tabel 1 menyajikan terjadi penurunan kandungan selulosa dan hemiselulosa dan peningkatan kandungan NDF dan ADF yang lebih tinggi pada lama pemeraman 14 hari dibandingkan pada lama pemeraman 7 hari.

Kandungan lignin pada lama pemeraman 21 hari adalah $19,43 \%$ dan nyata sangat rendah $(\mathrm{P} \leq 0,01)$ dibandingkan lama pemeraman 14 hari dan 7 hari. Hal ini menunjukkan proses degradasi lignin oleh mikroba berlangsung cukup lama (21 hari). Lamanya proses degradasi lignin oleh mikroba disebabkan karena tingginya kandungan lignin pada pelepah kelapa sawit yaitu 30,18\% (Febrina, 2016) serta kuatnya ikatan antara lignin dan selulosa serta hemiselulosa. Lignin merupakan polimer aromatik heterogen dengan bentuk yang tetap. Ikatan kovalen dan hydrogen mengikat lignin dengan selulosa dengan kuat membentuk lignoselulosa (Xu et al., 2016), oleh sebab itu dibutuhkan waktu yang lama untuk memecah ikatan lignin dengan selulosa dan hemiselulosa. Penambahan $4 \%$ urea pada fermentasi pelepah kelapa sawit dengan lama pemeraman 21 hari menurunkan kandungan lignin (Puastuti et al., 2015).

Peningkatan lama pemeraman menurunkan kandungan fraksi serat (Tabel 1). Hal ini menunjukkan semakin lama pemeraman maka aktivitas mikroba semakin besar dan semakin banyak kesempatan mikroba untuk mendegradasi pelepah kelapa sawit sehingga menghasilkan kandungan lignin yang lebih rendah. Hasil yang sama dilaporkan Febrina et al. (2020) penambahan ekskreta pada pelepah kelapa sawit dengan lama pemeraman 21 hari menghasilkan kandungan lignin 19,94\%. Interaksi antara jenis pengolahan dan lama pemeraman secara nyata $(\mathrm{P}<0,01)$ meningkatkan kandungan NDF dan ADF serta menurunkan kadar selulosa, hemiselulosa dan lignin pelepah kelapa sawit fermentasi. Kandungan lignin tertinggi terdapat pada pengolahan secara kimia dengan lama pemeraman 7 hari dan tidak berbeda dengan pengolahan secara biologi dengan lama pemeraman 7 hari. Hal ini menunjukkan pengolahan secara kimia dan biologi dengan lama pemeraman 7 hari belum maksimal mendegradasi ikatan lignoselulosa dengan lignohemiselulosa, tetapi kombinasi perlakuan kimia dan biologi secara nyata menurunkan kandungan lignin dibandingkan perlakuan kimia saja atau biologi saja.

Penambahan urea dan eksreta (kombinasi pengolahan secara kimia dan biologi) dengan lama pemeraman 21 hari menghasilkan kandungan lignin terendah yaitu $18,94 \%$ dan sangat nyata berbeda $(\mathrm{P} \leq 0,01)$ dengan perlakuan lainnya. Hasil yang sama dilaporkan Khairunnisa (2019), penambahan 5\% urea dan $10 \%$ feses ayam pada fermentasi jerami jagung dengan lama pemeraman 28 hari memberikan hasil terbaik. Hal ini menunjukkan semakin lama pemeraman dan semakin kompleks jenis pengolahan memberikan hasil yang lebih baik karena dapat menurunkan kandungan lignin kelapa sawit.

\section{SIMPULAN}

Interaksi antara jenis pengolahan dan lama pemeraman menurunkan kandungan selulosa, hemiselulosa dan lignin pelepah kelapa sawit. Perlakuan terbaik adalah penambahan 5\% urea dan $10 \%$ eksreta dengan lama pemeraman 
21 karena menghasilkan kandungan lignin terendah yaitu $18,94 \%$.

\section{DAFTAR PUSTAKA}

Direktorat Jenderal Perkebunan. 2018. Statistik Perkebunan Indonesia 2017-2019 (Kelapa Sawit). Direktorat Jenderal Perkebunan Kementrian Pertanian. Jakarta.

Diwyanto, K., D. Sitompul, Mantis, I.W. Mathius, Soentoro. 2003. Pengkajian pengembangan usaha sistem integrasi kelapa sawit. Prosiding Lokakarya Sistem Integrasi Kelapa Sawit-Sapi, 9-10 September 2003. Hal. 11-22. Bengkulu.

Febrina, D., N. Jamarun, M. Zain dan Khasrad. 2015. Kandungan fraksi serat pelepah sawit hasil biodelignifikasi menggunakan kapang Phanerochaete chrysosporium dengan penambahan mineral $\mathrm{Ca}$ dan $\mathrm{Mn}$. J. Peternakan, 17(3): 176-186.

Febrina. D. 2016. Pemanfaatan hasil biodeglinifikasi pelepah sawit menggunakan kapang Phanerochaete chrysosporium sebagai pengganti hijauan pakan pada ternak kambing. Disertasi. Universitas Andalas. Padang.

Febrina, D., R. Febriyanti., S. I. Zam., Zumarni. J. Juliantoni and A. Fatah. 2020. Nutritional content and characteristics of antimicrobial compounds from fermented oil palm fronds (Elaeis guineensis Jacq.). J. of Tropical Life Science, 10(1): 27-33.

Febriyossa, A., Nurmiati, dan Periadnadi. 2013. Potensi dan karakterisasi bakteri alami pencernaan ayam broiler pedaging (Gallus gallus domesticus L.) sebagai kandidat probiotik pakan ayam broiler. J. Biologi Universitas Andalas, 2(3): 201-106.

Imsya, A. Fariani., H. Neny dan I.S. Ika. 2005. Level penggunaan urea dalam amoniasi pelepah sawit. Laporan Penelitian. Fakultas Pertanian Universitas Sriwijaya. Palembang.

Imsya. A. 2007. Konsentrasi N amonia, kecernaan bahan kering dan bahan organik pelepah sawit hasil amoniasi secara in vitro. Prosiding Seminar Nasional Teknologi Peternakan dan Veteriner. Hal 111-115. Bogor.

Jaelani, A., S. Dharmawati dan B. Lesmana. 2015. Pengaruh lama penyimpanan hasil fermentasi pelepah sawit oleh Trichoderma sp. terhadap kandungan selulosa dan hemiselulosa. Ziraa'ah, 40(2): 165-174.
Jannah. R., Safika, M. Jalaluddin, Darmawi, Farida, dan D. Aliza. 2017. Jumlah koloni bakteri selulolitik pada sekum ayam kampung. JIMVET, 1(3):558-565.

Khairunnisa. N. 2019. Kualitas fisik dan kandungan nutrisi jerami jagung yang difermentasi dengan bahan aditif dan lama pemeraman yang berbeda. Skripsi. Fakultas Pertanian dan Peternakan UIN SUSKA RIAU. Pekanbaru.

Marjuki. 2013. Peningkatan Kualitas Jerami Padi Melalui Perlakuan Urea Amoniasi. Fakultas Peternakan Universitas Brawijaya. Malang.

Musnandar, E., R.A. Muthalib, dan A. Hamidah. 2010. Pemanfaatan Pelepah Sawit sebagai Pakan Berkualitas untuk Pertumbuhan dan Kualitas Daging Kambing. J. Penelitian Universitas Jambi: Seri Sains, 12(2) :7178.

Nurhaita., N. Jamarun., R. Saladin., L. Warly dan M. Zain. 2007. Efek beberapa Metoda Pengolahan Limbah Pelepah Kelapa Sawit terhadap Kandungan Gizi dan Kecernaan Secara In-Vitro. J. Ilmu-Ilmu Pertanian Indonesia, 2: 139-144.

Puastuti, W., T. Haryati, dan D. Yulistiani. 2015. Kecernaan (In vitro dan In sacco) pelepah sawit yang diolah dengan penambahan urea dan enzim. Prosiding Seminar Nasional Teknologi Peternakan dan Veteriner. 7-11 November 2015. Hal. 106114. Jakarta.

Sari. N. F. 2012. Identifikasi dan karakterisasi bakteri asam laktat pada kotoran ayam broiler sebagai agensi probiotik. Skripsi. Fakultas Matematika dan Ilmu Pengetahuan Alam Universitas Negeri Medan. Medan.

Spring, P. 1997. Understanding the Development of the Avian Gastrointestinal Microflora. In : an essential key for developing competitive exclusion products. University of Kentucky. Lexington. Pp: 149-160.

Steel, R.G.D. and J.H. Torrie. 1992. Pinciples and Procedures of Statictics. McGraw-Hill Book Co. Inc. New York.

Suharyadi. 2012. Studi penumbuhan dan produksi cacing sutra (Tubifex sp.) dengan pupuk yang berbeda dalam sistem resirkulasi. Tesis. Universitas Terbuka. Jakarta.

Wardani, S.C. 2013. Evaluasi komponen serat hasil biofermentasi pelepah kelapa sawit (Elaeis guineensis jacq) dengan Phanerochaete chrysosporium pada dosis inokulan dan lama pemeraman yang 
berbeda. Skripsi. Institut Pertanian Bogor. Bogor.

Xu, H., B. Li, and X. Mu. 2016. Review of alkalibased pretreatment to enhance enzymatic saccharification for lignocellulosic biomass conversion. Industrial and Engineering Chemistry Research, 55(32): 8691-8705 